\title{
Chemical composition and biological properties of Pleurotus spp. cultivated on peat moss and wheat straw
}

\author{
Juan Diego Valenzuela-Cobos ${ }^{1 *}$, René Oscar Rodríguez-Grimón', Diego Cunha Zied ${ }^{2}$, \\ Ana Grijalva-Endara ${ }^{3}$, María Fernanda Garcés-Moncayo ${ }^{4}$, María Eugenia Garín-Aguilar ${ }^{5}$, \\ Abraham Sánchez-Hernández ${ }^{6}$, Gustavo Valencia del Toro ${ }^{6}$
}

\begin{abstract}
${ }^{1}$ Universidad Espíritu Santo - Ecuador, ${ }^{2}$ Universidade Estadual Paulista (UNESP), Faculdade de Ciências Agrárias e Tecnológicas (FCAT), Dracena, SP, Brazil, ${ }^{3}$ Facultad de Ciencias Químicas, Universidad de Guayaquil- Ecuador, ${ }^{4}$ Facultad de Ingeniería, Escuela Ingeniería Ambiental. Universidad Nacional de Chimborazo. Km 1/vía a Guano s/n, Riobamba, 060150. Ecuador, ${ }^{5}$ Laboratorio de Farmacobiología de la Facultad de Estudios Superiores Iztacala, Universidad Nacional Autónoma de México. Av de los Barrios No.1. Los Reyes Iztacala, Tlalnepantla CP 54090. Edo. de México, México, ${ }^{6}$ Laboratorio de Cultivos Celulares de la Sección de Estudios de Posgrado e Investigación. UPIBI, Instituto Politécnico Nacional. Barrio La Laguna s/n Ticomán. Ciudad de México CP 07340, México
\end{abstract}

\section{A B S T R A C T}

The productivity parameters of 2 Pleurotus spp. cultivated with two mixtures of wheat straw (WS) and peat moss (MG) were evaluated, the chemical composition of the mushrooms and also the antioxidant, antibacterial activities of hexanic extracts of the fruit bodies were determined. Pleurotus strains were fructified using the mixture 1 (60\% of WS $+40 \%$ of MG) obtained the highest biological efficiencies, production rates and yields. The strain of Pleurotus ostreatus (XCO05) cultivated using the mixture $2(80 \%$ WS $+20 \%$ of MG) presented fruit bodies with highest protein content being of $25.28 \%$, and also the strain of Pleurotus djamor (XC007) fructified on the mixture 2 showed mushrooms with highest protein content being of $30.98 \%$. The highest antioxidant effect resulted in the hexanic extract of the Pleurotus ostreatus cultivated on $\mathrm{M} 2$ was found using the TBARS inhibition assay $\left(\mathrm{EC}_{50}=0.12 \mathrm{mg} \mathrm{mL}^{-1}\right)$, while the highest antioxidant activity showed the hexanic extract of the Pleurotus djamor produced on M1 was found using the TBARS inhibition assay $\left(\mathrm{EC}_{50}=0.21 \mathrm{mg} \mathrm{mL}^{-1}\right)$. The bactericidal effect of the hexanic extracts of Pleurotus ostreatus was obtained between 21.09 to $27.90 \mathrm{mg}^{\mathrm{mL}}-1$, whereas the bacteriostatic activity of the hexanic extracts of Pleurotus djamor was achieved since 19.82 to $30.98 \mathrm{mg} \mathrm{mL}^{-1}$. The results evidenced that the Pleurotus spp. cultivated on the mixture 2 presented highest protein content and better biological properties, encouraging the production of edible fungi strains and their use in the industrial field.

Keywords: Biological properties; Chemical composition; Pleurotus; Productivity

\section{INTRODUCTION}

Pleurotus spp. are the second specie with more production in the world (Valenzuela-Cobos et al., 2017; SánchezHernández et al., 2019) and are characterized for their high nutritional value (Zengin et al., 2015; Valenzuela-Cobos, 2018), can be taken as an important source of proteins, vitamins and minerals (Manzi et al., 1999). Pleurotus species are actively used in medical treatments with antioxidant properties, these antioxidants are important compounds that can be produced by living organisms, as can be obtained from many natural sources, and protect their health by damping active oxygen and free radicals (Bakir et al., 2018).
Pleurotus to produce fruit body requires tropical climates and can grow on a variety of organic materials such as: wheat straw, banana leaves, "palmareca" leaves, corn cob, corn straw and brachiaria straw (Valenzuela-Cobos, 2018; Iossi et al., 2018; Zied et al., 2018), however, there are not studies using supplements like peat moss in the mushroom cultivation being a common waste of the gardening and low cost. Supplements have been used successfully to improve mushroom yield and the use of alternative supplements in developing countries could be a good strategy. Research has already shown an increase of $34.4 \%$ in yield, in addition to increasing precocity, thus reducing the length of the crop cycle (Pardo-Giménez et al., 2016). The range of

\footnotetext{
${ }^{*}$ Corresponding author:

Juan Diego Valenzuela-Cobos, Universidad Espíritu Santo - Ecuador, Faculdade de Ciências Agrárias e Tecnológicas (FCAT), Dracena, SP, Brazil. E-mail: juan_diegova@hotmail.com
} 
supplement composition is characterized by the amount of protein since 24 to $62 \%$ and fat ranged from 0.8 to $19 \%$ of the material used as base supplement (Zied et al., 2019).

Mushroom possess the ability to degrade the lignin are known white-rot fungi, while the brown-rot fungi groups are able to attack cellulose and only modify lignin (Leonowicsz et al., 1999; Sánchez, 2009). Mushroom industry uses wastes from agro food industry decreasing the impact in the environment; these are usually rich in lignocellulosic compounds and are the result after processing of different kind of plants (Levanon et al., 1993; Philippoussis et al., 2007).

The purpose of this research was to determinate the productivity, morphology parameters and the chemical composition of the fruit bodies of two Pleurotus spp. cultivated in a mixture of wheat straw and peat moss, and evaluate their antioxidant and antibacterial activities.

\section{MATERIALS AND METHODS}

\section{Biological material}

In this experiment was used the following mushroom strains: Pleurotus ostreatus (XC005) and Pleurotus djamor (XC007). The strains are maintained on MEA dishes. Stocks of all strains are deposited at the fungal collection of Research and Development Laboratory of the AgroFarm Sánchez-Jaramillo.

\section{Mushroom cultivation}

Mushrooms were cultivated using like substrate a mixture of wheat straw (WS) with peat moss (PM), being M1 (80\% WS + 20\% PM) and M2 (60\% WS + 40\% PM). The substrates were hydrated, reaching $80 \%$ moisture. Subsequently, the mixture was placed (1 kg wet weight) in plastic bags and autoclaved for $4 \mathrm{~h}$ at $110{ }^{\circ} \mathrm{C}$. Then, the bags were cooled down and the inoculated with 10\% $(\mathrm{w} / \mathrm{w})$ of wheat grain and incubated in a dark room at temperature of $30 \pm 1^{\circ} \mathrm{C}$. Once the mycelium of the strain had colonized the substrate, the bags with substrate were transferred to a room with favorable conditions for the fructification: relative humidity was maintained between 85 and $90 \%$, temperature of $25 \pm 1^{\circ} \mathrm{C}$, air recirculation and period of illumination of $12 \mathrm{~h}$.

\section{Productivity characteristics}

Productivity of the mushroom was evaluated based on the biological efficiency (BE; fresh weight of harvested mushrooms/substrate dry weight x 100), yield (Y; fresh weight of harvested mushrooms/substrate fresh weight $\mathrm{x}$ 100) and production rate, daily average biological efficiency (PR; ratio of $\mathrm{BE} /$ total number of production days starting from inoculation) (Salmones et al., 1997).

\section{Chemical composition of the fruit bodies}

Mushrooms were dried at $60^{\circ} \mathrm{C}$ for $24 \mathrm{~h}$ and then milled to perform proximal analysis using standard methods. The humidity, ash, fat, protein $(\mathrm{N} \times 4.38)$, and crude fiber contents were determined using (AOAC, 2005). Total carbohydrates were obtained via the difference method, where carbohydrates $=100-($ crude protein + fat + crude fiber + ash) (Valencia del Toro et al., 2018).

\section{Chemical composition of the agricultural wastes}

To determinate the chemical composition of the substrates a proximal analysis was realized: acid detergent fiber (ADF), neutral detergent fiber (NDF), hemicellulose, cellulose, and lignin were determined using the methodology of (GaitánHernández et al., 2006; Vásquez-Véliz et al., 2018).

\section{Hexanic extraction procedure}

The hexanic extract was taken of the crude fat determination of the mushroom. After that, the extract was evaporated using a rotary evaporator (Büchi R-210; Flawil, Switzerland) under reduced pressure.

\section{Evaluation of antioxidant activity}

The DPPH radical-scavenging activity assay and the thiobarbituric acid reactive substance (TBARS) assay were determined using the methodology of (Mocan et al., 2018).

\section{Antibacterial activity}

In the evaluation of the antibacterial properties only was considered the dry fruiting bodies obtained in the cultivation of Pleurotus ostreatus (XC005) and Pleurotus djamor (XC007) growth on the mixture M2 (60\% WS + 40\% PM) due to their highest protein content in comparison with the mushroom cultivated in the mixture M1 $(80 \%$ WS + $20 \%$ PM).

In this experiment was used the following Gram-negative bacteria: Psendomonas aeruginosa (ABN 187), Salmonella typhimurium (ABN 572) and the following Grampositive bacteria: Micrococcus flavus (ABP 147) and Staphylococcus aureus (ABP 784). Bioassay is carried out by the microdilution method. To determinate the antibacterial activities of the hexanic extracts of the mushrooms were used the methodology of (Mocan et al., 2018).

\section{Statistical analysis}

In all analyzes, a completely randomized design and the results were studied using one-way analysis of variance (ANOVA) to determine the significance of individual differences at $\mathrm{p}<0.05$ level, of productivity and chemical composition of the fruit bodies, the chemical composition of the substrates before and after of the harvest, and the antioxidant activities of the hexanic extracts of the mushrooms, when statistical differences were found, the 
Duncan Test with $\alpha=0.05$ was applied. The analyses were carried out using statistical software (Statgraphic ver. 16).

\section{RESULTS AND DISCUSSION}

\section{Productivity parameters}

Table 1 shows the productivity parameters of the Pleurotus ostreatus and Pleurotus djamor strains produced using mixtures of wheat straw (WS) with peat moss (PM), being M1 $(80 \%$ WS $+20 \% \mathrm{PM})$ and M2 (60\% WS + 40\% PM).

The strain of Pleurotus djamor cultivated on M1 showed the highest productivity parameters: biological efficiency of $88.09 \%$, productivity rate of $1.64 \%$ and yield of $28.86 \%$, while the strain of Pleurotus djamor cultivated on M2 (Fig. 1) presented productivity: biological efficiency of $56.50 \%$, productivity rate of $1.23 \%$ and yield of $18.68 \%$. The strain of Pleurotus ostreatus produced on M1 (Fig. 2) presented the highest productivity: biological efficiency of $116.19 \%$, productivity rate of $2.01 \%$ and yield of $38.06 \%$, whereas the strain of Pleurotus ostreatus cultivated on the mixture M2 showed productivity: biological efficiency of $73.10 \%$, productivity rate of $1.50 \%$ and yield of $24.17 \%$.

Philippoussis (2009) cultivated one strain of P. ostreatus and one strain of $P$. pulmonarius on wheat straw presenting biological efficiencies since 85.40 to $90.90 \%$, also produced these strains on softwood residues presenting biological efficiencies ranged from 48.10 to $76.00 \%$. Mandeel et al. (2005) cultivated one strain of Pleurotus ostreatus on four different substrates (paper, cardboard, fiber, sawdust) showed biological efficiencies ranged from 59.6 to $117.5 \%$. The uses of different substrates improve the biological efficiency, production rate and yield (Royse et al., 2004; Yang et al., 2013). The variability of the productivity parameters is directly related to the strains and the supplementation in the substrates (Sánchez et al., 2002; Gaitán-Hernández et al., 2014). Nutrients in the composition of the substrate are one of the factors that limit colonization, which influences in the edible mushroom production (Philippoussis, 2009).

\section{Chemical characteristics of the fruit bodies}

The chemical composition of the mushrooms of the Pleurotus ostreatus and Pleurotus djamor strains produced using the mixtures M1 (80\% WS $+20 \% \mathrm{PM})$ and M2 (60\% WS $+40 \% \mathrm{PM})$ is presented in Table 2 .

The mushrooms of the Pleurotus ostreatus strain produced on the mixtures M1 and M2 showing similar moisture contents ranged from 91.06 to $92.55 \%$, whereas the fruiting bodies of the Pleurotus djamor strain cultivated on the two mixtures presenting similar moisture values since 93.64 to $95.62 \%$. The fruit bodies of the Pleurotus ostreatus strain cultivated on the mixtures M1 and M2 presenting similar fat contents between 1.27 to $1.37 \%$, while the mushrooms of the Pleurotus djamor strain produced on the two mixtures showing similar fat values since 1.55 to $1.78 \%$. The moisture and fat content of the fruit bodies is influenced by the composition of the

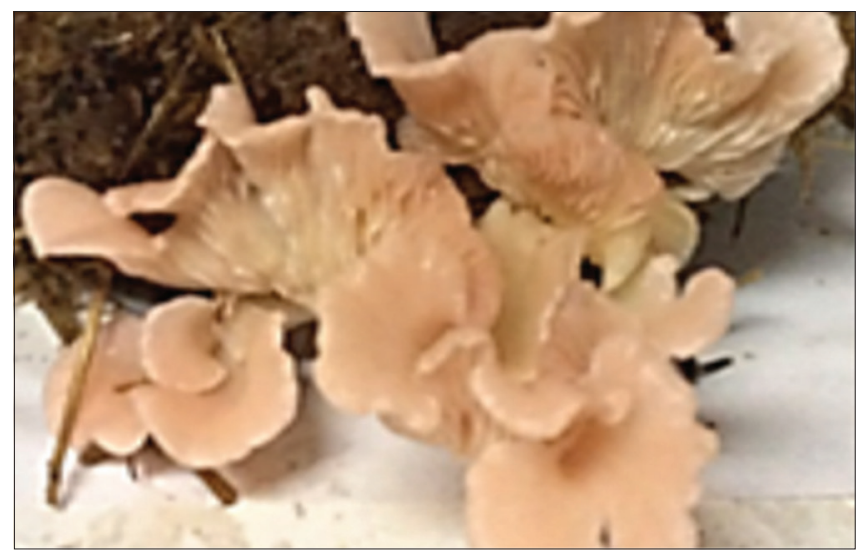

Fig 1. Pleurotus djamor cultivated in the mixture $\mathrm{M}$.

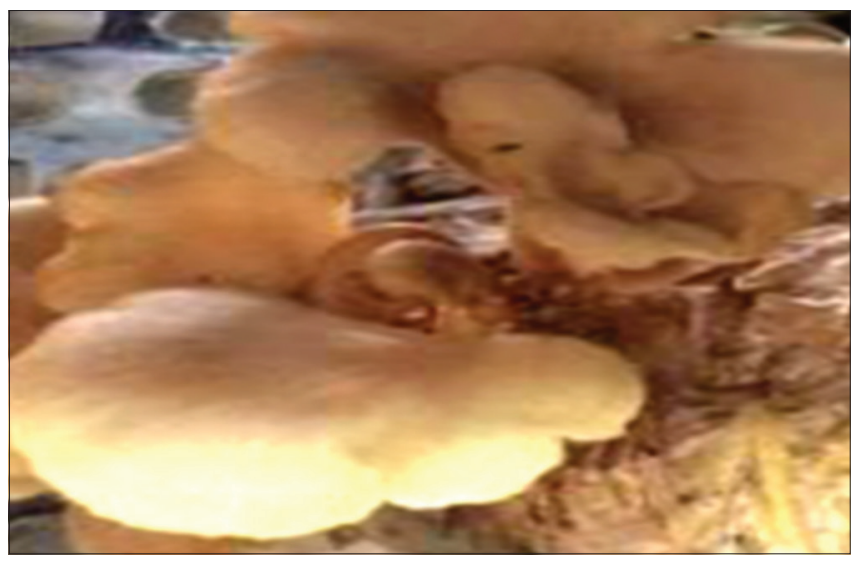

Fig 2. Pleurotus ostreatus cultivated in the mixture M.

Table 1: Productivity parameters of Pleurotus spp. produced on the two different mixtures

\begin{tabular}{llccccc}
\hline Strains & Mixtures & Precocity (days) & Total cultivation time (days) & Biological efficiency (\%) & Production rate (\%) & Yield (\%) \\
\hline XC005 & M1 & $32.00 \pm 1.87^{\mathrm{b}}$ & $57.80 \pm 1.30^{\mathrm{b}}$ & $116.19 \pm 25.52^{\mathrm{b}}$ & $2.01 \pm 0.43^{\mathrm{b}}$ & $38.06 \pm 8.36^{\mathrm{b}}$ \\
& M2 & $22.60 \pm 2.51^{\mathrm{a}}$ & $49.00 \pm 2.35^{\mathrm{a}}$ & $73.10 \pm 5.61^{\mathrm{a}}$ & $1.50 \pm 0.16^{\mathrm{a}}$ & $24.17 \pm 1.86^{\mathrm{a}}$ \\
XC007 & M1 & $27.40 \pm 0.89^{\mathrm{B}}$ & $53.80 \pm 1.79^{\mathrm{B}}$ & $88.09 \pm 13.58^{\mathrm{B}}$ & $1.64 \pm 0.25^{\mathrm{B}}$ & $28.86 \pm 4.45^{\mathrm{B}}$ \\
& M2 & $20.20 \pm 2.68^{\mathrm{A}}$ & $46.00 \pm 1.22^{\mathrm{A}}$ & $56.50 \pm 14.95^{\mathrm{A}}$ & $1.23 \pm 0.35^{\mathrm{A}}$ & $18.68 \pm 4.94^{\mathrm{A}}$ \\
\hline
\end{tabular}

*All values are means \pm standard deviation of ten replicates. Lowercase letters indicate difference between the productivity parameters of Pleurotus ostreatus obtained on the two different mixtures, while uppercase letters indicate difference between the productivity parameters of Pleurotus djamor obtained on the two different mixtures according to Duncan's test $(p<0.05), n=10$. M1=60\% of WS $+40 \%$ of $M G, M 2=80 \%$ of $W S+20 \%$ of $M G$ 
substrates used in the production of the mushroom (Liu et al., 2005; Valencia del Toro et al., 2018).

Fruit bodies of the Pleurotus ostreatus strain cultivated on M1 showed highest crude fiber content being of $12.67 \%$, also the Pleurotus djamor strain produced on M1 presented highest crude fiber value being of $9.23 \%$. The high fiber content in edible fungi promotes intestinal regulation and the elimination of undigested food (Silva et al., 2002).

The highest content of crude protein was showed by the mushrooms of the Pleurotus ostreatus strain cultivated on M2 being of $25.28 \%$, and also the fruit bodies of the Pleurotus djamor strain produced on M2 showing the highest protein content being of $30.98 \%$. Supplementation of substrates to raise the nutritional value available for the mushrooms tends to produce carpophores with less water and higher protein content (Pardo-Giménez et al., 2016). Crisan and Sands (1978) indicated that the protein content of the fungi depends on the composition of the substrates used in the cultivation, the size of the pileus, and the strain.

The mushrooms of the Pleurotus ostreatus strain cultivated on the mixtures M1 and M2 presenting similar ash values since 8.67 to $9.26 \%$, while the fruit bodies of the Pleurotus djamor strain produced on the two mixtures showing similar ash contents ranged from 8.30 to $8.77 \%$. The highest content of carbohydrate was showed by the mushrooms of the Pleurotus ostreatus strain cultivated on M1 being of $53.28 \%$, while the fruit bodies of the Pleurotus djamor strain produced on M1 presenting the highest carbohydrate value being of $51.76 \%$.

Similar studies have been previously reported, Fernandes et al. (2015) presented fruit bodies of one Pleurotus ostreatus strain cultivated on 3 different substrates (paper remnants) presenting moisture contents between 84.30 to $91.00 \%$, crude protein ranged from 9.29 to $14.70 \%$, fat since 1.18 to $1.68 \%$, ash between 5.69 to $15.90 \%$, carbohydrates in a range between 73.20 to $78.60 \%$. The nutritional composition of the fruit bodies is influenced by the substrate used in the cultivation of the mushrooms and the strain (Manzi et al., 2001).

\section{Chemical characteristics of the substrates}

The contents of acid detergent fiber (ADF), neutral detergent fiber (NDF), hemicellulose, cellulose and lignin varied between the two mixtures: M1 (80\% WS $+20 \%$ PM) and M2 (60\% WS $+40 \%$ PM) used in the cultivation of Pleurotus spp. (Table 3). The lowest values of neutral detergent fiber (NDF), acid detergent fiber (ADF) and cellulose was showed by the mixture (M1) in the mushroom production.

The values of acid detergent fiber, neutral detergent fiber, hemicellulose, cellulose and lignin decreased in the substrates used in the fructifications of all strains.

Table 2: Chemical composition of the mushrooms of Pleurotus spp. cultivated on the two different mixtures

\begin{tabular}{llcccccc} 
Strains & Mixtures & Moisture (\%) & Fat (\%) & Crude protein (\%) & Ash (\%) & Crude fiber (\%) & Carbohydrate (\%) \\
\hline XC005 & M1 & $92.55 \pm 2.36^{\mathrm{a}}$ & $1.37 \pm 0.20^{\mathrm{a}}$ & $24.01 \pm 0.92^{\mathrm{a}}$ & $8.67 \pm 2.08^{\mathrm{a}}$ & $12.67 \pm 3.79^{\mathrm{b}}$ & $53.28 \pm 0.64^{\mathrm{b}}$ \\
& M2 & $91.06 \pm 3.12^{\mathrm{a}}$ & $1.27 \pm 0.08^{\mathrm{a}}$ & $25.28 \pm 0.50^{\mathrm{b}}$ & $9.26 \pm 0.40^{\mathrm{a}}$ & $11.77 \pm 2.44^{\mathrm{a}}$ & $52.42 \pm 2.40^{\mathrm{a}}$ \\
XC007 & M1 & $95.62 \pm 2.03^{\mathrm{A}}$ & $1.78 \pm 0.56^{\mathrm{A}}$ & $28.46 \pm 5.42^{\mathrm{A}}$ & $8.77 \pm 1.60^{\mathrm{A}}$ & $9.23 \pm 2.32^{\mathrm{B}}$ & $51.76 \pm 3.32^{\mathrm{B}}$ \\
& M2 & $93.64 \pm 2.36^{\mathrm{A}}$ & $1.55 \pm 0.28^{\mathrm{A}}$ & $30.98 \pm 4.35^{\mathrm{B}}$ & $8.30 \pm 0.42^{\mathrm{A}}$ & $7.86 \pm 2.25^{\mathrm{A}}$ & $51.31 \pm 3.64^{\mathrm{A}}$ \\
\hline
\end{tabular}

${ }^{*}$ All values are means \pm standard deviation of ten replicates. Lowercase letters indicate difference between the chemical composition of the mushrooms of Pleurotus ostreatus obtained on the two different mixtures, whereas uppercase letters indicate difference between the chemical composition of the mushrooms of Pleurotus djamor obtained on the two different mixtures according to Duncan's test $(p<0.05), n=10$. M1 $1=60 \%$ of WS $+40 \%$ of MG, M2 $=80 \%$ of WS $+20 \%$ of $M G$

Table 3: Chemical composition of WS and AP before and after harvest

\begin{tabular}{|c|c|c|c|c|c|c|}
\hline Strains & Mixtures & Acid Detergent Fiber (\%) & Neutra Detergent Fiber (\%) & Lignin (\%) & Hemicelullose (\%) & Celullose (\%) \\
\hline \multirow[t]{4}{*}{ Control } & M1 & $38.77 \pm 0.26^{\mathrm{B}}$ & $65.82 \pm 0.76^{B}$ & $11.98 \pm 0.06^{\mathrm{B}}$ & $27.04 \pm 0.52^{B}$ & $53.84 \pm 0.70^{\mathrm{B}}$ \\
\hline & & $(0 \%)$ & $(0 \%)$ & $(0 \%)$ & $(0 \%)$ & $(0 \%)$ \\
\hline & M2 & $40.42 \pm 0.46^{c}$ & $68.98 \pm 0.20^{c}$ & $12.93 \pm 0.11^{b}$ & $28.56 \pm 0.66^{b}$ & $56.04 \pm 0.23^{c}$ \\
\hline & & $(0 \%)$ & $(0 \%)$ & $(0 \%)$ & $(0 \%)$ & $(0 \%)$ \\
\hline \multirow{4}{*}{ xC005 } & M1 & $27.95 \pm 5.20^{A}$ & $48.33 \pm 5.26^{A}$ & $8.63 \pm 1.56^{A}$ & $20.38 \pm 0.54^{\mathrm{A}}$ & $39.71 \pm 6.82^{A}$ \\
\hline & & $(27.91 \%)$ & $(26.57 \%)$ & $(27.96 \%)$ & $(24.63 \%)$ & $(26.24 \%)$ \\
\hline & M2 & $30.80 \pm 0.27^{b}$ & $48.26 \pm 3.82^{b}$ & $10.23 \pm 1.56^{a}$ & $17.46 \pm 4.09^{a}$ & $38.03 \pm 2.27^{b}$ \\
\hline & & (23.80\%) & $(30.04 \%)$ & $(20.88 \%)$ & (38.86\%) & $(32.14 \%)$ \\
\hline \multirow[t]{3}{*}{ XC007 } & M1 & $29.02 \pm 2.40^{\mathrm{A}}$ & $48.20 \pm 0.10^{A}$ & $10.11 \pm 1.05^{\mathrm{A}}$ & $19.18 \pm 2.34^{\mathrm{A}}$ & $38.06 \pm 0.96^{A}$ \\
\hline & & $(25.15 \%)$ & $(26.77 \%)$ & $(15.60 \%)$ & $(29.07 \%)$ & (29.31\%) \\
\hline & M2 & $\begin{array}{c}23.78 \pm 4.33^{a} \\
(41.17 \%)\end{array}$ & $\begin{array}{c}42.25 \pm 1.29^{a} \\
(38.75 \%)\end{array}$ & $\begin{array}{c}9.08 \pm 0.94^{a} \\
(29.77 \%)\end{array}$ & $\begin{array}{c}18.47 \pm 3.09^{a} \\
(35.32 \%)\end{array}$ & $\begin{array}{c}33.17 \pm 2.20^{\mathrm{a}} \\
(40.81 \%)\end{array}$ \\
\hline
\end{tabular}

${ }^{*}$ All values are means \pm standard deviation of ten measurements. Uppercase letters indicate difference between the chemical composition of the substrate $M 1$, while lowercase letters indicate difference between chemical composition of the substrate M2 according to Duncan's test ( $p<0.05)$, $n=10$. M1=60\% of WS $+40 \%$ of MG, M2 $=80 \%$ of WS $+20 \%$ of MG. ${ }^{*}$ The biodegradation of the acid detergent fiber, neutral detergent fiber, cellulose, hemicellulose and lignin was calculated according to the following equation: \%Biodegradation=100-(\%Final composition of the substrate*100/\% Initial composition of the substrate). Values in brackets represent the percentage of biodegradation of the substrates 
The mixtures M1 and M2 used in the fructification of Pleurotus djamor presented the highest degradation of cellulose with values of 29.31 and $40.81 \%$ respectively. For otherwise, the mixture M1 used in the production of Pleurotus djamor showed the highest degradation of hemicellulose (29.07\%), whereas the mixture M2 used in the cultivation of Pleurotus ostreatus presented the highest degradation of hemicellulose $(38.86 \%)$.

On the other hand, the mixture M1 used in the cultivation of Pleurotus ostreatus presented the highest degradation of lignin (27.96\%), while the mixture M2 used in the production of Pleurotus djamor showed the highest degradation of lignin $(29.77 \%)$.

Similar studies have been reported, Bae et al. (2006) cultivated Pleurotus ostreatus, Pleurotus eryngii, Flammulina velutupes using a mixture of sawdust, rice bran and corn cob presenting the following chemical composition of the mixture after harvest: neutral detergent fiber of $78.20 \%$, acid detergent fiber of $60.40 \%$, lignin of $20.00 \%$,

Table 4: Antioxidant activity of the hexanic extracts of the mushrooms of Pleurotus spp produced on the two different mixtures

\begin{tabular}{|c|c|c|c|}
\hline \multirow[b]{2}{*}{ Strains } & \multirow[b]{2}{*}{ Mixtures } & $\begin{array}{l}\text { Radical scavenging } \\
\text { activity }\end{array}$ & $\begin{array}{c}\text { Lipid } \\
\text { peroxidation } \\
\text { inhibition }\end{array}$ \\
\hline & & $\begin{array}{c}\text { DPPH scavenging } \\
\text { activity }\left(\mathrm{EC}_{50} ; \mathrm{mg} \mathrm{mL}^{-1}\right)\end{array}$ & $\begin{array}{c}\text { TBARS } \\
\left(\mathrm{EC}_{50} ; \mathrm{mg} \mathrm{mL}^{-1}\right)\end{array}$ \\
\hline \multirow[t]{2}{*}{ XC005 } & M1 & $7.80 \pm 0.20^{\mathrm{b}}$ & $0.20 \pm 0.02^{\mathrm{b}}$ \\
\hline & M2 & $7.10 \pm 0.26^{\mathrm{a}}$ & $0.12 \pm 0.01^{a}$ \\
\hline \multirow[t]{2}{*}{ XC007 } & M1 & $8.23 \pm 0.15^{A}$ & $0.21 \pm 0.03^{A}$ \\
\hline & M2 & $8.53 \pm 0.16^{B}$ & $0.28 \pm 0.15^{\mathrm{B}}$ \\
\hline
\end{tabular}

${ }^{*}$ All values are means \pm standard deviation of three replicates. Lowercase letters indicate difference between the antioxidant activity of the hexanic extracts of the mushrooms of Pleurotus ostreatus obtained on the two different mixtures, while uppercase letters indicate difference between the antioxidant activity of the hexanic extracts of the mushrooms of Pleurotus djamor obtained on the two different mixtures according to Duncan's test $(p<0.05)$, $n=3$. M1 $=60 \%$ of $W S+40 \%$ of MG, M2 $=80 \%$ of $W S+20 \%$ of MG. The results are presented in $\mathrm{EC}_{50}$ values, which means that higher values correspond to lower antioxidant potential. $\mathrm{EC}_{50}$ : extract concentration corresponding to $50 \%$ of antioxidant activity. Trolox $\mathrm{EC}_{50}$ values: $0.053 \mathrm{mg} \mathrm{mL}^{-1}$ (DPPH scavenging activity) and $0.029 \mathrm{mg} \mathrm{mL}^{-1}$ (TBARS inhibition) hemicellulose of $17.80 \%$, cellulose of $40.40 \%$, while (Kwak et al., 2008) produced Pleurotus eryngii using a mixture of sawdust, rice bran, corn cob supplemented with poultry litter showing the following composition of the substrate after harvest: hemicellulose content of $13.90 \%$, cellulose of $32.20 \%$, lignin of $17.40 \%$. Blanchette (1991) indicated that the degradation of lignocellulosic residues is influenced by the characteristic of the substrate, the environmental factors and the genetic factors between the strains.

\section{Antioxidant activity of hexanic extracts of Pleurotus ostreatus and Pleurotus djamor}

Table 4 shows the antioxidant activity of the hexanic extracts of Pleurotus ostreatus and Pleurotus djamor cultivated on the two mixtures were evaluated through two assays involving different mechanisms: radical scavenging activity and lipid peroxidation inhibition. For the radical scavenging (DPPH scavenging activity) and the lipid peroxidation inhibition (TBARS) the results are presented in $\mathrm{EC}_{50}$ values, indicating that higher values correspond to lower antioxidant potential. In Table 4 can see that the hexanic extract of the P. ostreatus strain cultivated on the mixture M2 showed the highest measured antioxidant effect was found in the TBARS inhibition assay $\left(\mathrm{EC}_{50}=0.12 \mathrm{mg} \mathrm{mL}^{-1}\right)$, followed by DPPH scavenging activity $\left(\mathrm{EC}_{50}=7.10 \mathrm{mg} \mathrm{mL}^{-1}\right)$, whereas the hexanic extract of the Pleurotus djamor strain cultivated on the mixture M1 showed the highest measured antioxidant effect was found in the TBARS inhibition assay $\left(\mathrm{EC}_{50}=8.23 \mathrm{mg} \mathrm{mL}^{-1}\right)$, followed by DPPH scavenging activity $\left(\mathrm{EC}_{50}=0.21 \mathrm{mg} \mathrm{mL}^{-1}\right)$. Similar results have been observed in the study of Sudha et al. (2012) showed the antioxidant effect of 3 different extracts (ethyl acetate, methanol and hot water) of Pleurotus presenting values of $\mathrm{EC}_{50}$ between 4.20 to $7.00 \mathrm{mg} \mathrm{mL}^{-1}$ for the $\mathrm{DPPH}$ scavenging assay, and values of $\mathrm{EC}_{50}$ since 0.08 to $0.12 \mathrm{mg}$ $\mathrm{mL}^{-1}$ for TBARS inhibition assay. The maintenance of equilibrium between free radical production and antioxidant defenses is an essential condition for normal organism functioning, and an eventual imbalance is reflected through the accumulation of damaged cell

Table 5: Antimicrobial activity of the hexanic extracts of the mushrooms of Pleurotus spp. cultivated on the mixture M2

\begin{tabular}{|c|c|c|c|c|c|}
\hline \multirow[t]{2}{*}{ Samples } & & \multicolumn{2}{|c|}{ Gram-negative bacteria } & \multicolumn{2}{|c|}{ Gram-positive bacteria } \\
\hline & & Pseudomonas aeruginosa & Salmonella typhimurium & Micrococcus flavus & Staphylococcus aureus \\
\hline \multirow[t]{2}{*}{ XC005 } & MIC & $11.38 \pm 0.12$ & $14.28 \pm 0.17$ & $18.11 \pm 0.08$ & $11.67 \pm 0.79$ \\
\hline & MBC & $21.52 \pm 0.15$ & $22.19 \pm 0.22$ & $27.90 \pm 0.13$ & $21.09 \pm 0.44$ \\
\hline \multirow[t]{2}{*}{ XC007 } & MIC & $9.33 \pm 0.57$ & $11.46 \pm 5.42$ & $8.19 \pm 0.60$ & $10.96 \pm 0.12$ \\
\hline & $\mathrm{MBC}$ & $23.55 \pm 0.28$ & $30.98 \pm 4.35$ & $19.82 \pm 0.03$ & $25.02 \pm 0.70$ \\
\hline Ampicillin & $\begin{array}{l}\text { MIC } \\
\text { MBC }\end{array}$ & $\begin{array}{l}0.29 \pm 0.06 \\
0.35 \pm 0.04\end{array}$ & $\begin{array}{l}0.31 \pm 0.02 \\
0.74 \pm 0.11\end{array}$ & $\begin{array}{l}0.20 \pm 0.03 \\
0.44 \pm 0.01\end{array}$ & $\begin{array}{l}0.23 \pm 0.03 \\
0.86 \pm 0.05\end{array}$ \\
\hline Streptomycin & $\begin{array}{l}\text { MIC } \\
\text { MBC }\end{array}$ & $\begin{array}{l}0.09 \pm 0.02 \\
0.21 \pm 0.01\end{array}$ & $\begin{array}{l}0.06 \pm 0.01 \\
0.18 \pm 0.05\end{array}$ & $\begin{array}{l}0.10 \pm 0.02 \\
0.30 \pm 0.19\end{array}$ & $\begin{array}{l}0.13 \pm 0.02 \\
0.36 \pm 0.09\end{array}$ \\
\hline
\end{tabular}

*All values are means \pm standard deviation of three replicates. M2 $=80 \%$ of $\mathrm{WS}+20 \%$ of MG. ${ }^{*}$ MIC-Minimum inhibitory concentrations; MBC-minimum bactericidal concentrations 
structures (cell membranes, proteins). Compounds from wild mushrooms have been described as excellent natural antioxidants (Ferreira et al., 2009).

\section{Antimicrobial activity of hexanic extracts of Pleurotus ostreatus and Pleurotus djamor}

To determinate the antimicrobial activity was used the hexanic extracts of Pleurotus ostreatus and Pleurotus djamor cultivated on M2 and the following bacteria: Pseudomonas aeruginosa, Salmonella typhimurium, Micrococcus flavus and Staphylococcus aureus using the microdilution method (Table 5).

The results of the antimicrobial activity indicates that the hexanic extract of Pleurotus ostreatus possesses a good antibacterial activity on Pseudomonas aeruginosa, whereas the extract of Pleurotus djamor takes a good antibacterial activity on Micrococcus flavus. The bacteriostatic concentration of the hexanic extract of Pleurotus ostreatus presented values since 21.09 to $27.90 \mathrm{mg} \mathrm{mL}^{-1}$ for the four bacteria, and the bactericidal concentration of the hexanic extract of Pleurotus djamor showed values ranged from 19.82 to $30.98 \mathrm{mg} \mathrm{mL}^{-1}$ for the four bacteria. Similar results have been observed, Dharmaraj et al. (2014) reported bacteriostatic concentration using two different extracts (acetone and dimethyl sulfoxide) of Pleurotus djamor presenting values since 7.00 to $12.00 \mathrm{mg} \mathrm{mL}^{-1}$ for Pseudomonas aeruginosa and Escherichia coli.

\section{CONCLUSIONS}

The highest productivity of Pleurotus spp. cultivated using the mixture 1 obtained the highest biological efficiencies, production rates and yields.

The results obtained of the protein content and biological activities represent a positive predictor to increase the development of edible fungi strains to raise the commercial production at industrial level.

\section{ACKNOWLEDGEMENTS}

We would like to thank to the Escuela de Ciencias Ambientales de la Universidad Espíritu Santo - Ecuador.

\section{Authors' contributions}

Juan Diego Valenzuela-Cobos and Ana Grijalva-Endara have developed the experimental plan. Diego Cunha Zied and Abraham Sánchez-Hernández performed the analysis. René Oscar Rodríguez-Grimón verified the analytical methods and discussed the results and wrote the final manuscript. María Eugenia Garín-Aguilar and Gustavo Valencia del Toro supervised the findings of this work.

\section{REFERENCES}

AOAC. 2005. Official Methods of Analysis. $18^{\text {th }}$ ed. Association Analytical Chemists, Gaithersburg, Maryland, USA.

Bae, J. S., Y. I. Kim, S. H. Jung, Y. G. Oh and W. S. Kwak. 2006. Evaluation on feed-nutritional value of spent mushroom (Pleurotus osteratus, Pleurotus eryngii, Flammulina velutupes) substrates as a roughage source of ruminants. J Anim. Sci. Technol. 48: 237-246.

Blanchette, R. A. 1991. Delignification by wood-decay fungi. Annu. Rev. Phytopathol. 29: 381-398.

Bakir, T., M. Karadeniz and S. Unal. 2018. Investigation of antioxidant activities of Pleurotus ostreatus stored at different temperatures. Food Sci. Nutr. 6: 1040-1044.

Crisan, E. V. and A. Sands. 1978. Nutritional value. In: S. T. Chang and W. A. Hayes (Eds.), The Biology and Cultivation of Edible Mushroom. Academic Press Inc., USA, pp. 137-165.

Dharmaraj, K., T. Kuberan and R. Mahalakshmi. 2014. Comparison of nutrient contents and antimicrobial properties of Pleurotus djamor, Agaricus bisporus and Ganoderma tsugae. Int J. Curr. Microbiol. Appl. Sci. 3: 518-526.

Fernandes, A., L. Barros, A. Martins, P. Herbert and I. C. F. Ferreira. 2015. Nutritional characterisation of Pleurotus ostreatus (Jacq ex Fr.) P. Kumm. produced using paper scraps as substrate. Food Chem. 169: 396-400.

Ferreira, I. C. F., L. Barros and R. M. V. Abreu. 2009. Antioxidants in wild mushrooms. Curr. Med. Chem. 16: 1543-1560.

Gaitán-Hernández, R., M. Esqueda, A. Gutierrez, A. Sánchez, M. Beltrán-García and G. Mata. 2006. Bioconversion of agrowastes by Lentinula edodes: The high potential of viticulture residues. Appl. Microbiol. Biotechnol. 71: 432-439.

Gaitán-Hernández, R., N. Cortés and G. Mata. 2014. Improvement of yield of the edible and medicinal mushroom Lentinula edodes on wheat straw by use of supplemented spawn. Braz. J. Microbiol. 45: 467-474.

lossi, M. R., J. D. Valenzuela-Cobos, F. J. Gea-Alegria and D. Zied. 2018. Pleurotus spp. cultivation on Brachiaria sp. straw treatment with alkaline water: Oyster mushroom and substrate treatment. Braz. J. Microbiol. 49: 64-67.

Kwak, W. S., S. H. Jung and Y. I. Kim. 2008. Broiler litter supplementation improves storage and feed-nutritional value of sawdust-based spent mushroom substrate. Bioresour. Technol. 99: 2947-2955.

Leonowicsz, A., A. Matuszewska, J. Luterek, D. Ziegenhagen, M. Wojtas-Wasilewska, N. S. Cho, M. Hofrichter and J. Rogalski. 1999. Biodegradation of lignin by white rot fungi. Fungal Genet. Biol. 27: 175-185.

Levanon, D., N. Rothschild, O. Danai and S. Masaphy. 1993. Bulk treatment of substrate for the cultivation of Shiitake mushrooms (Lentinula edodes) on straw. Bioresour. Technol. 45: 63-64.

Liu, J., C. Vijayakumar, C. A. Hall-lii, M. Hadley and C. E. Wolf-Hall. 2005. Sensory and chemical analyses of oyster mushrooms (Pleurotus sajor-caju) harvested from different substrates. J. Food Sci. 70: 586-592.

Mandeel, Q. A., A. A. Al-Laith and S. A. Mohamed. 2005. Cultivation of oyster mushrooms (Pleurotus spp.) on various lignocellulosic wastes. World J. Microbiol. Biotechnol. 4: 601-607.

Manzi, P., L. Gambelli, S. Marconi, V. Vivanti and L. Pizzoferrato. 1999. Nutrients in edible mushrooms: An inter-species comparative study. Food Chem. 65: 477-482.

Manzi, P., A. Aguzzi and L. Pizzoferrato. 2001. Nutritional value of mushrooms widely consumed in Italy. Food Chem. 73: 321-325. 
Mocan, A., A. Fernandes, L. Barros, G. Crişan, M. Smiljković, M. Soković and I. C. F. Ferreira. 2018. Chemical composition and bioactive properties of the wild mushroom Polyporus squamosus (Huds.) Fr: A study with samples from Romania. Food Sci. Nutr. 9: 160-170.

Pardo-Giménez, A., L. Catalán, J. Carrasco, M. Álvarez-Ortí, D. C. Zied and J. E. Pardo. 2016. Effect of supplementing crop substrate with defatted pistachio meal on Agaricus bisporus and Pleurotus ostreatus production. J. Sci. Food Agric. 96: 3838-3845.

Philippoussis, A., P. Diamantopoulou and C. Israilides. 2007. Productivity of agricultural residues used for the cultivation of the medicinal fungus Lentinula edodes. Int. Biodeterior. Biodegradation. 59: 216-219.

Philippoussis, A. N. 2009. Production of mushrooms using agroindustrial residues as substrates. In: P. S. Nee'Nigam, A. Pandey (Eds.), Biotechnology for Agro-Industrial Residues Utilization, Springer Science, Berlin, German, pp. 163-196.

Royse, D. J., T. W. Rhodes, S. Ohga and J. E. Sanchez. 2004. Yield, mushroom size and time to production of Pleurotus cornucopiae (oyster mushroom) grown on switch grass substrate spawned and supplemented at various rates. Bioresour. Technol. 91: 85-91.

Salmones, D., R. Gaitán-Hernández, R. Pérez and G. Guzmán. 1997. Estudios sobre el género Pleurotus VIII. Interacción entre crecimiento micelial y productividad. Rev. Iberoam. Micol. 14: 173-176.

Sánchez, A., F. Ysunza, M.J. Beltrán-García and M. Esqueda. 2002. Biodegradation of viticulture wastes by Pleurotus: A source of microbial and human food and its potencial use in animal feeding. J. Agric. Food Chem. 50: 2537-2542.

Sánchez, C. 2009. Lignocellulosic residues: Biodegradation and bioconversion by fungi. Biotechnol. Adv. 27: 185-194.

Sánchez-Hernández, A., J. D. Valenzuela Cobos, J. Herrera Martínez, R. V. Arce, Y. M. Gómez y Gómez, P. B. Z. Segura, M. E. G. Aguilar, H. L. Lara and G. Valencia del Toro. 2019. Characterization of Pleurotus djamor neohaplonts recovered by production of protoplasts and chemical dedikaryotization. 3 Biotech. 9: 24.

Silva, S. O., S. M. Gomes and E. Clemente. 2002. Chemical composition of Pleurotus pulmonarius (Fr.) Quél., substrates and residue after cultivation. Braz. Arch. Biol. Technol. 45: 531-535.

Sudha, G., S. Vadivukkarasi, R. I. Shree and P. Lakshmananm. 2012. Antioxidant activity of various extracts from an edible mushroom Pleurotus eous. Food Sci. Biotechnol. 21: 661-668.

Valencia del Toro, G., M. E. Ramírez-Ortiz, G. Flores-Ramírez, M. R. Costa-Manzano, F. Robles-Martínez, M. E. G. Aguilar and H. Leal-Lara. 2018. Effect of Yucca schidigera bagasse as substrate for oyster mushroom on cultivation parameters and fruit body quality. Rev. Mex. Ing. Quim. 17: 835-846.

Valenzuela-Cobos, J. D., E. D. Páramo, R. V. Arce, A. SánchezHernández, M. E. G. Aguilar, H. L. Lara and G. Valencia del Toro. 2017. Production of hybrid strains among Pleutorus and Lentinula and evaluation of their mycelial growth kinetics on malt extract agar and wheat grain using the Gompertz and Hill models. Emirates J. Food Agric. 29: 927-935.

Valenzuela-Cobos, J. D. 2018. Evaluación Morfológica, Nutricional y de Productividad de Cepas Híbridas de Pleurotus lentinula. Ph.D. Dissertation, Unidad Profesional Interdisciplinaria de Biotecnología, Ciudad de México, México.

Vásquez-Véliz, G., C. Vargas-Farías, M. Garín-Aguilar, G. Valencia del Toro, L. Jara-Bastidas and J. Valenzuela-Cobos. 2018. Ethanol production using lignocellulosic wastes. Ital. J. Food Sci. 198-203.

Yang, W., F. Guo and Z. Wan. 2013. Yield and size of oyster mushroom grown on rice wheat straw basal substrate supplemented with cotton seed hull. Saudi J. Biol. Sci. 20: 333-338.

Zengin, G., C. Sarikurkcu, A. Aktumsek, S. Uysal, R. Ceylan, F. Anwar and M. H. Solak. 2015. A comparative fatty acid compositional analysis of different wild species of mushrooms from Turkey. Emirates J. Food Agric. 27: 532-536.

Zied, D. C., C. E. C. Caitano, A. Pardo-Gimenez, E. S. Dias, M. L. Zeraik and J. E. Pardo. 2018. Using of appropriated strains in the practice of compost supplementation for Agaricus subrufescens production. Front. Sustain. Food Syst. 2: 26.

Zied, D. C., E. P. Prado, E. S. Dias, J. E. Pardo and A. PardoGimenez. 2019. Use of peanut waste for oyster mushroom substrate supplementation oyster mushroom and peanut waste. Braz. J. Microbiol. 50: 1021-1029. 